Vol. 8(21), pp. 763771,3 June, 2014

DOI: 10.5897/JMPR2014.5437

Article Number: 1CD429A45212

ISSN 1996-0875

Copyright (C) 2014

Author(s) retain the copyright of this article

http://www.academicjournals.org/JMPR

Journal of Medicinal Plant Research

Full Length Research Paper

\title{
Phenolics of Achillea fragrantissima growing in Egypt and its cytotoxic activity
}

\author{
Riham Omar Bakr ${ }^{1 *}$, Reem Khedr Arafa ${ }^{2}$, Ahmed Mohamed Al-Abd ${ }^{3,4}$ and \\ Hisham Mohamed Elshishtawy ${ }^{5}$ \\ ${ }^{1}$ Pharmacognosy Department, Faculty of Pharmacy, October University for Modern Sciences and Arts (MSA), \\ Giza, Egypt. \\ ${ }^{2}$ Pharmaceutical Chemistry Department, Faculty of Pharmacy, Cairo University, Cairo, Egypt. \\ ${ }^{3}$ Pharmacology Department, National Research Center, Dokki, Egypt. \\ ${ }^{4}$ Pharmacology and Toxicology Department, Faculty of Pharmacy, King Abdulaziz University, Jeddah, Saudi Arabia. \\ ${ }^{5}$ Microbial Molecular Biology Department, Agricultural Genetic Engineering Research Institute, Giza, Egypt.
}

Received 2 April, 2014; Accepted 23 May, 2014

\begin{abstract}
Achillea fragrantissima Sch. Bip. (Asteraceae) has been reputed in folk medicine of the Arabia region and Egypt for the treatment of many diseases. Air dried aerial parts of $\boldsymbol{A}$. fragrantissima were extracted with $70 \%$ aqueous ethanol and fractionated with petroleum ether, dichloromethane, $n$-butanol and ethyl acetate fractions. Among them, dichloromethane showed the highest activity and was subjected to separation and purification by various chromatographic techniques. Five flavones and one phenolic acid were isolated and identified as acerosin (1), cirsimaritin (2), cirsiliol (3), luteolin (4), apigenin (5) and caffeic acid (6), respectively. Acerosin, the flavone of higher concentration isolated for the first time in genus Achillea, showed promising cytotoxic and radical scavenging activity. Molecular modeling of acerosin indicated its ability to bind in a co-crystallized ligand-like manner with kinase enzyme (FAK), namely with Cys502, alongside extra binding interactions with Glu430, Lys454 and Asp564. Total protein profiling of $\boldsymbol{A}$. fragrantissima DNA was performed using polyacrylamide gel electrophoresis (PAGE) for characterization of plant where the total number of bands recovered was 4.
\end{abstract}

Key words: Acerosin, hepatocellular carcinoma, molecular modeling, DPPH, kinase enzyme (FAK).

\section{INTRODUCTION}

The Egyptian flora is very rich in its diversity, with hundreds of plants used in traditional medicine since antiquity when the ancient Egyptians recorded thousands of plants and their uses in Ebers papyrus (Saleh, 2003). The genus, Achillea L., belongs to Asteraceae (Compositae), the largest family of vascular plants. Achillea contains around 130 flowering species (Saeidnia et al., 2011). Due to numerous medicinal properties, aerial parts of the members of the genus are widely used in traditional medicine. Only two species are present in Egypt: Achillea fragrantissima Sch. Bip. (Asteraceae) and Achillea santolina L. (Asteraceae). A. fragrantissima has

*Corresponding author. E-mail: rehambkr@yahoo.com. Tel: (+202)-01006516956.

Author(s) agree that this article remain permanently open access under the terms of the Creative Commons Attribution License 4.0 International License 
been reputed in folk medicine in the Arabian region as hypoglycemic (Yaniv et al., 1987) and also for the treatment of gastrointestinal disturbances (Segal et al., 1987). Many phytochemical and pharmacological studies have been performed to reveal the importance of $A$. fragrantissima. Several flavonoids were isolated, including swertisin 2"-arabinosideafroside, cirsimaritin, chrysoplenol, cirsiliol, eupatilin-7-methyl ether, isovitexin 4'-methyl ether and acacetin-6-C-(6"-acetyl- $\beta$-Dglucopyranoside)-8-C- $\alpha$-L-arabinopyranoside (Ahmed et al., 1988; Ahmed et al., 1989; ElSayed, 2010; Ezzat and Salama, 2014). Also, the fatty acids, lauric, myristic, palmitic, stearic, linoleic, linolenic, oleic, and diacyl glycerol of palmitic acid, in addition to the bitter substance keissoside, were isolated. Sesquiterpene lactones represent a major class in $A$. fragrantissima, containing 13-O-desacetyl-1- $\beta$-hydroxyafraglouclide, achilloide $A$, $1 \alpha, 4 \alpha$-endoperoxypseudoguaia-7, 10- diene- $6 \beta, 12$-olide. Furthermore, taraxasterol and pseudotaraxasterol acetates were identified. In addition, analysis of $A$. fragrantissima revealed the presence of 6-oxo-S-hydroxysantolina-1, 4-diene; 4,5,8-trihydroxy-santolin-1-ene; 5,8epoxy-4,6-dihydroxy-santofin-1-ene (Ahmed et al., 1990).

As one of the most important folk medicines in the Arabian region and in Egypt, several biological studies were performed, demonstrating anti-neuroinflammatory, strong antioxidant and hepatoprotective activities (Elmann et al., 2011a, b; Khaled et al., 2010). Remarkable antiviral activity was observed against poliomyelitis-1 virus (Soltan and Zaki, 2009), in addition to potent larvicidal (Sathiyamoorthy et al., 1997) and antidiabetic activities (Yaniv et al., 1987; Ezzat and Salama, 2014). Studying its anticancer activity, $A$. fragrantissima was revealed as potent inducer of differentiation, cell cycle arrest and apoptosis in chronic myeloid leukemia and T cell lymphoma (Alenad et al., 2013). Cirsiliol (5, 3', 4'-trihydroxy-6,7-dimethoxyflavone) isolated from $A$. fragrantissima showed spasmolytic activity, as it antagonizes the spasmodic effects, inhibits $\mathrm{Ca}^{2+}$ influx and stimulates $\mathrm{Ca}^{2+}$ released from intracellular stores (Mustafa et al., 1992). Applications of biochemical genetic techniques have an important potential to provide a new tool for the study of wild species, as well as domesticated species. Electrophoresis methods are considered a rapid and accurate test to identify and characterize species. Total protein profiling obtained by polyacrylamide gel electrophoresis (PAGE), is frequently used in resolving systematic relationships (Paradies and Ohms, 1987; Lioi et al., 1999; Karihaloo et al., 2002).

A. fragrantissima, very rich in its phenolic content, still represents an attractive field of study. The aim of this study was to shed light on its importance as a cytotoxic agent against hepatocellular carcinoma of wide occurrence in Egypt, and isolation of its bioactive compounds and in silico trials in order to identify the mechanisms behind which the bioactive compounds elicit performed as a means of identification and characterization of this plant species growing in Sinai.

\section{MATERIALS AND METHODS}

\section{General experimental procedures}

For column chromatography, microcrystalline cellulose (E. Merck, Darmstadt, Germany) and sephadex LH-20 (Pharmacia, Uppsala, Sweden) were used. For paper chromatography, Whatman no. 1 sheets and Whatman no. 3 sheets for screening and preparative paper chromatography (PPC) (Whatman Ltd, Maidstone, Kent, England) were used. The pure compounds were visualized under UV light $(254$ and $365 \mathrm{~nm})$. Solvent systems $\mathrm{S}_{1}(n-$ $\mathrm{BuOH} / \mathrm{HOAc} / \mathrm{H}_{2} \mathrm{O}: \quad 4: 1: 5 \mathrm{v} / \mathrm{v} / \mathrm{v}$ top layer) and $\mathrm{S}_{2}(15 \%$ aqueous $\mathrm{HOAc}$ ) were used. The nuclear magnetic resonance (NMR) spectra were recorded at $300\left({ }^{1} \mathrm{H}\right)$ and $125\left({ }^{13} \mathrm{C}\right) \mathrm{MHz}$ on a Varian Mercury 300 . The results were reported as $\delta(\mathrm{ppm})$ values relative to TMS in the convenient solvents. Electron ionization-mass spectrometry (EIMS) analyses were run on a Shimadzu QP-2010 Plus mass spectrometer at $70 \mathrm{ev}$ and $220^{\circ} \mathrm{C}$ ion source temperature. UV analyses for pure samples were recorded on $\mathrm{MeOH}$ solutions and with different diagnostic UV shift reagents on a Shimadzu UV spectrophotometer (1800 UV probe).

\section{Plant material and extraction}

The aerial parts of $A$. fragrantissima were collected from Saint Catherine, South Sinai, Egypt in September, 2010, during the flowering stage. Authentication of the plant was performed by Dr. Mona M. Marzouk (Ph.D.), Department of Phytochemistry and Plant Chemosystematics, National Research Center (NRC), Cairo, Egypt. A voucher specimen (No RS05) was deposited at the herbarium of Pharmacognosy Department, Faculty of Pharmacy, October University for Modern Science and Arts, Egypt. Powdered air dried aerial parts were exhaustively extracted with $70 \%$ aqueous ethanol under reflux $\left(4 \mathrm{~L} \times 6,70^{\circ} \mathrm{C}\right.$ and $\left.4 \mathrm{~h}\right)$. The residue left after the evaporation of the solvent $(70 \mathrm{~g})$ was dissolved in $400 \mathrm{ml} \mathrm{MeOH} / \mathrm{H}_{2} \mathrm{O}$ $(9: 1)$. After that, it was successively extracted with petroleum ether (Pet. ether) $(4 \times 300 \mathrm{ml})$; dichloromethane $\left(\mathrm{CH}_{2} \mathrm{Cl}_{2}\right)(7 \times 300 \mathrm{ml})$; ethyl acetate $(\mathrm{EtOAc})(5 \times 300 \mathrm{ml})$ and n-butanol $(\mathrm{BuOH})(5 \times 300$ $\mathrm{ml}$ ). Pet. ether, $\mathrm{CH}_{2} \mathrm{Cl}_{2}$, EtOAc and $\mathrm{BuOH}$ extracts were evaporated under reduced pressure to give yields equal to $0.7 \mathrm{~g}$ (yield: $1 \%$ ), $18.2 \mathrm{~g}$ (yield: $26 \%$ ), $4.62 \mathrm{~g}$ (yield: $6.6 \%$ ) and $6.44 \mathrm{~g}$ (yield: $9.2 \%$ ), respectively. The final aqueous phase with a yield of $22.61 \mathrm{~g}$ (yield: $32.3 \%$ ) was also evaporated to dryness. All extracts were tested for their effects against hepatocellular carcinoma.

\section{Cytotoxic activity}

\section{Sulforhodamine B (SRB) assay}

Human hepatocellular cancer cell line, HePG2, was obtained from Vacsera (Giza, Egypt). The cytotoxicity of the total $70 \%$ aqueous ethanol extract (AEE) and its successive extracts were tested against liver (HePG2) cancer cell line by sulforhodamineB (SRB) assay, as described by Skehan et al. (1990) and Al-Abd et al. (2008) at concentrations of $1000,100,10,1$ and $0.1 \mu \mathrm{g} / \mathrm{ml}$. The dose response curves of different fractions were analyzed using $E_{\max }$ model (Equation 1) and percentage of cell viability was calculated using the following equation: 


$$
\% \text { Cell viability }=(100-\mathrm{R}) \times\left(1-\frac{[\mathrm{D}]^{\mathrm{m}}}{\mathrm{K}_{\mathrm{d}}^{\mathrm{m}}+[\mathrm{D}]^{\mathrm{m}}}\right)+\mathrm{R}
$$

In this equation, $\mathrm{R}$ is the residual unaffected fraction (the resistance fraction), [D] is the drug concentration used, $K_{d}$ is the dose of the drug that produces a $50 \%$ reduction of the maximum inhibition rate and $\mathrm{m}$ is a Hill-type coefficient. $\mathrm{IC}_{50}$ was defined as the drug concentration required to reduce fluorescence to $50 \%$ of that of the control (that is, $K_{d}=I C_{50}$ when $R=0$ and $E_{\max }=100-R$ ). The concentration required to reduce cell viability by $50 \%\left(\mathrm{IC}_{50}\right)$ was determined using the sigmoid $\mathrm{E}_{\max }$ model. The extract with the highest activity and lowest $\mathrm{IC}_{50}$ was explored for its major constituents.

\section{Microtetrazoline (MTT) assay}

The major constituent with higher concentration was exposed to cytotoxic investigation. Cell viability was assessed against HePG2, using SRB assay (as previously described) and MTT (3- (4, 5dimethylthiazol-2-yl) -2, 5-diphenyltetrazolium bromide) assay via mitochondrial dependent reduction of yellow MTT to purple formazan (Mosmann, 1983). Cells were incubated either alone (negative control) or with different concentrations of the tested samples to give final concentrations of $100,50,25,12.5,6.25$, 3.125 , and $1.56 \mu \mathrm{g} / \mathrm{ml}$. A positive control (doxorubicin) was used as a known cytotoxic natural agent, which gives $100 \%$ lethality under the same conditions (Thabrew et al., 1997). The percentage of change in viability was calculated according to Equation 2:

Viability $(\%)=[($ Reading of sample - Reading of negative control) 1] $\times 100$

\section{Evaluation of the antioxidant effect (in vitro)}

The activity of 1, 1-diphenylpicrylhydrazil (DPPH) was estimated according to the method described by Shimada et al. (1992). Radical scavenging activity was measured at $517 \mathrm{~nm}$ (Equation 3).

DPPH scavenging effect $\left.(\%)=\left[\left(A_{0}-A_{1}\right) / A_{0}\right) \times 100\right]$

Where: $A_{0}$ is the absorbance of the control reaction (DPPH) and $A_{1}$ is the absorbance of the test extract. Ascorbic acid was used as standard (Oktay et al., 2003).

\section{Quantitative estimation of total phenolic and flavonoid contents}

The total phenolic content (TPC) was determined through the FolinCiocalteau reagent (FCR), using gallic acid as standard (Sellappan and Akoh, 2002). TPC was expressed as milligram of gallic acid equivalent (GAE) per milligram of plant extract for each fraction, based on gallic acid calibration curve (standard curve equation: $y=$ $\left.0.0011 x+0.0009, R^{2}=0.9867\right)$, having the absorptivity maxima at $765 \mathrm{~nm}$. Quantitative estimation of flavonoid contents was performed via aluminum chloride assay, using quercetin as standard. Flavonoid content (FC) was expressed as milligram of quercetin equivalent (QE) per milligram of extract for each fraction, based on quercetin calibration curve, having the absorptivity maxima at $415 \mathrm{~nm}$ (the standard curve equation:

$y=0.005 x-0.0198, R^{2}=0.9774$ ) (Chang et al., 2002; Kosalec et al., 2004).

\section{Isolation}

$\mathrm{CH}_{2} \mathrm{Cl}_{2}$ extract $\left(15 \mathrm{~g}\right.$ ) exhibiting the lowest $\mathrm{IC}_{50}<50 \mu \mathrm{g} / \mathrm{ml}$ was considered as the most active extract. Additionally, it was subjected to chromatographic fractionation using cellulose column $(200 \mathrm{~g}, 120$ $\times 5 \mathrm{~cm}$ ) and eluted with saturated $n$-butanol, giving 46 fractions of $30 \mathrm{ml}$ each, collected into 4 major fractions that were monitored by comparative paper chromatography (comp-PC) and UV-light, by means of $\mathrm{S}_{1}, \mathrm{~S}_{2}$ and different spray reagents $\left.\left(\mathrm{AlCl}_{3} \text { and } \mathrm{FeCl}\right)_{3}\right) \mathrm{Fr}-1$ (1-10, $380 \mathrm{mg})$; Fr-2 (11-20, $450 \mathrm{mg})$; Fr-3 (21-32, $280 \mathrm{mg})$; and Fr4 (32-46, $360 \mathrm{mg})$. Fr-1, Fr-2, Fr-3 and Fr-4 were further fractionated using PPC and $S_{2}$ solvent. The isolated compounds were finally purified using sephadex $\mathrm{LH}-20$. Compounds $1,25 \mathrm{mg}$ was purified from $\mathrm{Fr}-1$; Compounds 2, $15 \mathrm{mg}$ and 3, $12 \mathrm{mg}$ were isolated from Fr-2; Compounds $4,11 \mathrm{mg}$ and $5,12 \mathrm{mg}$ were isolated from $\mathrm{Fr}-3$; and Compounds $6,13 \mathrm{mg}$ was isolated from $\mathrm{Fr}-4$.

\section{Docking experiment}

The molecular model of compound 1 (acerosin, 6,8,4'trimethoxyluteolin), the major constituent in the $\mathrm{CH}_{2} \mathrm{Cl}_{2}$ extract, was built in its dissociated form using standard bond lengths and angles, with the MOE software suite version 2008. Following geometry optimization, a Monte Carlo conformational search was carried out with the ConfSearch module implemented in MOE. All molecular mechanics computations were performed with the Merck Force Field (MMFF94s). The experimental crystallographic structure of the kinase enzyme FAK complex was retrieved from the Protein Data Bank (PDB ID 3PXK). Missing hydrogens were added to the enzyme and partial charges were calculated. After removing the cocrystallized inhibitor, docking of acerosin was carried out using MOE. The target protein was kept rigid while the ligand was left free to explore the conformational space inside the enzyme cavity; 200 separate docking simulations were run using default parameters.

\section{Protein banding analysis and Electrophoresis}

Total cellular proteins were extracted from the sample, followed by analysis with electrophoresis, staining and destaining for protein gel according to Laemmli (1970) and Stegmann et al. (1988). The gel was placed between two sheets of cellophane membrane, dried on a gel drier for $2 \mathrm{~h}$ and photographed. The banding profile and the molecular weight of each band were calculated by visual comparison to a molecular weight marker.

\section{RESULTS}

\section{SRB assay}

Cytotoxic activities of different extracts (Pet. ether, $\mathrm{CH}_{2} \mathrm{Cl}_{2}$, EtOAc, $\mathrm{BuOH}, \mathrm{AEE}$ ) of $A$. fragrantissima were assessed against HePG2 cell line using SRB assay (Table 1). With zero resistant fraction, $\mathrm{CH}_{2} \mathrm{Cl}_{2}$ fraction exhibited the highest effect against liver cell carcinoma $\left(\mathrm{IC}_{50}=38.7 \pm 2.13 \mu \mathrm{g} / \mathrm{ml}\right)$, compared with other extracts showing cytotoxic effects, but with less potency and with 
Table 1. Cytotoxicity of $A$. fragrantissima fraction against liver (HePG-2) cell line.

\begin{tabular}{lcc}
\hline \multirow{2}{*}{ Fraction } & \multicolumn{2}{c}{ Liver cell carcinoma (HePG-2) } \\
\cline { 2 - 3 } & $\mathbf{I C}_{50}(\boldsymbol{\mu g} / \mathbf{m l})$ & $\mathbf{R} \%$ \\
\hline $\mathrm{CH}_{2} \mathrm{Cl}_{2}$ & $38.7 \pm 2.13$ & 0 \\
$\mathrm{BuOH}$ & $78.6 \pm 3.51$ & 1.64 \\
$\mathrm{EtOAc}$ & $88.9 \pm 3.67$ & 2.2 \\
$\mathrm{AEE}$ & $127.8 \pm 4.1$ & 1.4 \\
Pet. Ether & $104.2 \pm 2.5$ & 11.3 \\
\hline
\end{tabular}

$\mathrm{R}$, residual unaffected fraction.

Table 2. Phenolic, flavonoid and radical scavenging activity of different extracts of $A$. fragrantissima.

\begin{tabular}{lcccc}
\hline \multirow{2}{*}{ Parameter } & \multirow{2}{*}{${\text { Phenolic }(\mathbf{m g} / \mathbf{g ~ G A E})^{\mathbf{a}}}$} & \multirow{2}{*}{${\text { Flavonoid }(\mathbf{m g} / \mathbf{g ~ Q E})^{\mathbf{b}}}$} & & \multicolumn{2}{c}{ Radical scavenging activity } \\
\hline $\mathrm{BuOH}$ & $19.948 \pm 0.54$ & $20 \pm 0.18$ & $30.6 \pm 2.6$ & $53.7 \pm 2.94$ \\
$\mathrm{EtOAC}$ & $34.52 \pm 0.63$ & $23 \pm 0.2$ & $5.4 \pm 0.52$ & $11.9 \pm 1.04$ \\
$\mathrm{CH}_{2} \mathrm{ICl}_{2}$ & $16.98 \pm 0.21$ & $29 \pm 0.17$ & $25.5 \pm 1.3$ & $49.3 \pm 1.9$ \\
$\mathrm{AEE}$ & $18.56 \pm 0.18$ & $11.58 \pm 0.11$ & $35.5 \pm 1.86$ & $60.4 \pm 1.6$ \\
\hline
\end{tabular}

${ }^{\mathrm{a} G A E: ~ G a l l i c ~ A c i d ~ E q u i v a l e n t ~ a n d ~}{ }^{\mathrm{b}} \mathrm{QE}:$ Quercetin Equivalent.

resistant fractions ranging from 1.4 to $11.3 \%$.

\section{Evaluation of the antioxidant effect (in vitro)}

Comparing the radical scavenging activities of the different extracts, $\mathrm{IC}_{50}$ and $\mathrm{IC}_{90}$ were evaluated and presented in Table 2. EtOAc showed the lowest $\mathrm{IC}_{50}(5.4$ $\pm 0.52 \mu \mathrm{g} / \mathrm{ml}$ ), followed by dichloromethane, while the highest $\mathrm{IC}_{50}(35.3 \pm 1.86 \mu \mathrm{g} / \mathrm{ml})$ with the lowest radical scavenging activity was observed with AEE.

\section{Quantitative estimation of total phenolic and flavonoid contents}

The TPC and TF of different extracts of $A$. fragrantissima were estimated colorimetrically. EtOAC showed the highest phenolic content (34.52 $\pm 0.63 \mathrm{mg} / \mathrm{g} \mathrm{GAE})$ using FCR while $\mathrm{CH}_{2} \mathrm{Cl}_{2}$ showed the highest flavonoid content $(29 \pm 0.17 \mathrm{mg} / \mathrm{g} \mathrm{QE})$ using the aluminium chloride assay (Table 2).

\section{Identification of isolated compounds}

\section{Compound (1), Acerosin (6, 8, 4'-trimethoxyluteolin)}

The yellowish amorphous powder had Rf values 0.88
(S1) and 0.4 (S2) on pc. It gave a purple color changing to yellow upon exposure to ammonia vapor. UV $\lambda_{\max }$ $(\mathrm{nm}):(\mathrm{MeOH})$ 258, $350 \mathrm{~nm} ;(+\mathrm{NaOH})$ 272, 413; (+ $\mathrm{NaOAc})$ 268, 350; (+ $\left.\mathrm{NaOAc} / \mathrm{H}_{3} \mathrm{BO}_{3}\right) 260,371 ;\left(+\mathrm{AlCl}_{3}\right)$ 259, 373; (+ $\left.\mathrm{AlCl}_{3} / \mathrm{HCl}\right)$ 259, 374. El-MS (m/z) $360[\mathrm{M}-\mathrm{H}]^{+}$ $.{ }^{1} \mathrm{H}-\mathrm{NMR}\left(300 \mathrm{MHz}, \mathrm{CD}_{3} \mathrm{OD}\right): \delta 7.69(1 \mathrm{H}, \mathrm{d}, J=2 \mathrm{~Hz}, \mathrm{H}-$ $\left.2^{\prime}\right), 7.56\left(1 \mathrm{H}, \mathrm{dd}, J=2,7.6 \mathrm{~Hz}, \mathrm{H}-6^{\prime}\right), 6.96(1 \mathrm{H}, \mathrm{d}, J=7.6$ $\left.\mathrm{Hz}, \mathrm{H}-5^{\prime}\right), 6.78(1 \mathrm{H}, \mathrm{s}, \mathrm{H}-3), 3.76\left(3 \mathrm{H}, \mathrm{s}, \mathrm{OCH}_{3}\right), 3.84(3 \mathrm{H}$, $\left.\mathrm{s}, \mathrm{OCH}_{3}\right), \quad 3.95\left(3 \mathrm{H}, \mathrm{s}, \mathrm{OCH}_{3}\right) \cdot{ }^{13} \mathrm{C}-\mathrm{NMR}(125 \mathrm{MHz}$, $\mathrm{CD}_{3} \mathrm{OD}$ ): $\delta 163.8$ (C-2), 102.9 (C-3), 182.4 (C-4), 148.2 (C-5), 132 (C-6), 145.2 (C-7), 128 (C-8), 150.1 (C-9), 103 (C-10), 121.3 (C-1'), 110.0 (C-2'), 148.0 (C-3'), 145 (C-4'), 115.9 (C-5'), $120.3\left(\mathrm{C}^{\prime}\right), 60.5\left(6-\mathrm{OCH}_{3}\right), 57\left(8-\mathrm{OCH}_{3}\right)$, $55.8\left(4^{\prime}-\mathrm{OCH}_{3}\right)$.

\section{Cirsimaritin (2)}

Yellowish amorphous powder had Rf values 0.65 (S1) and 0.5 (S2) on pc. It gave a purple color changing to yellow upon exposure to ammonia vapor. UV $\lambda_{\max }(\mathrm{nm})$ : $(\mathrm{MeOH}) 272$, 334; (+ NaOH) 280, 404; (+ NaOAc) 274, $334 ;\left(+\mathrm{NaOAc} / \mathrm{H}_{3} \mathrm{BO}_{3}\right)$ 274, 334; $\left(+\mathrm{AlCl}_{3}\right) 274,303,356$; (+ $\left.\mathrm{AlCl}_{3} / \mathrm{HCl}\right) 273$, 358. El-MS: m/z $315[\mathrm{M}+\mathrm{H}]^{+} .{ }^{1} \mathrm{H}-\mathrm{NMR}$ (300 MHz, $\left.\mathrm{CD}_{3} \mathrm{OD}\right): \delta 7.89\left(2 \mathrm{H}, \mathrm{d}, J=8.7 \mathrm{~Hz}, \mathrm{H}-2^{\prime}, \mathrm{H}^{\prime} 6^{\prime}\right)$, $6.92\left(2 \mathrm{H}, \mathrm{d}, J=8.7 \mathrm{~Hz}, \mathrm{H}-3^{\prime}, \mathrm{H}-5^{\prime}\right), 6.9(1 \mathrm{H}, \mathrm{s}, \mathrm{H}-8), 6.8$ $(1 \mathrm{H}, \mathrm{s}, \mathrm{H}-3), 3.22\left(3 \mathrm{H}, \mathrm{s}, \mathrm{OCH}_{3}\right), 3.9\left(3 \mathrm{H}, \mathrm{s}, \mathrm{OCH}_{3}\right) .{ }^{13} \mathrm{C}-$ NMR (125 MHz, CD ${ }_{3} \mathrm{OD}$ ): $\delta 182.2$ (C-4), 164.1 (C-2), 161 (C-4'), 158.4 (C-7), 152.8 (C-9), 152.1 (C-5), 131.8 (C-6), 
Table 3. Data matrix illustrating the presence and absence of bands in the seed protein electrophoretic banding pattern A. fragrantissima species.

\begin{tabular}{ccc}
\hline No. & M.Wt. (KDa) & A. fragrantissima \\
\hline 1 & 272 & 0 \\
2 & 223 & 0 \\
3 & 215 & 1 \\
4 & 134 & 1 \\
5 & 72 & 0 \\
6 & 59 & 1 \\
7 & 44 & 1 \\
8 & 39 & 0 \\
\hline
\end{tabular}

128.5 (C-2' and C-6'), 121 (C-1'), 116 (C-3' and C-5'), 105 (C-10), 102 (C-3), 91.3 (C-8), 60.0 (6-OMe), 56.4 (7$\mathrm{OMe})$.

\section{Cirsiliol (3)}

Yellowish armorphous powder had Rf values 0.75 (S1) and 0.57 (S2) on pc. It gave a purple color that changed to yellow upon exposure to ammonia vapor. UV $\lambda_{\max }$ $(\mathrm{nm}):(\mathrm{MeOH})$ 255, 348; $(+\mathrm{NaOH})$ 257, 413 with increased intensity; $\quad(+\mathrm{NaOAc}) \quad 255,349 ; \quad(+$ $\left.\mathrm{NaOAc} / \mathrm{H}_{3} \mathrm{BO}_{3}\right)$ 255, 406; (+ $\left.\mathrm{AlCl}_{3}\right)$ 258, 423; (+ $\left.\mathrm{AlCl}_{3} / \mathrm{HCl}\right)$ 259, 372. El-MS m/z $330[\mathrm{M}]^{+}$. ${ }^{1} \mathrm{H}-\mathrm{NMR}(300$ $\left.\mathrm{MHz}, \mathrm{CD}_{3} \mathrm{OD}\right): \delta 7.89\left(1 \mathrm{H}, \mathrm{dd}, J=8.7 \mathrm{~Hz}, \mathrm{H}-6^{\prime}\right), 7.62(1$ $\left.\mathrm{H}, \mathrm{d}, J=2 \mathrm{~Hz}, \mathrm{H}-2^{\prime}\right), 6.97\left(1 \mathrm{H}, J=8.7 \mathrm{~Hz}, \mathrm{H}-5^{\prime}\right), 6.65$ $(1 \mathrm{H}, \mathrm{m}, \mathrm{H}-8), 6.3(1 \mathrm{H}, \mathrm{s}, \mathrm{H}-3), 3.83,3.73(2 \times 3 \mathrm{H}, 2 \times \mathrm{s}$, $\left.2 \times \mathrm{OCH}_{3}\right) \cdot{ }^{13} \mathrm{C}-\mathrm{NMR}\left(125 \mathrm{MHz}, \mathrm{CD}_{3} \mathrm{OD}\right): \delta 182.1(\mathrm{C}-4)$, 164.2 (C-2), 158.6 (C-7), 152.6 (C-9), 152.1 (C-5), 149.9 (C-4'), 145.8 (C-3'), 131.9 (C-6), 121.4 (C-1'), 105.0 (C10), 119.0 (C-6'), 115.9 (C-5'), 113.5 (C-2'), 102.7 (C-3), 91.5 (C-8), 60.0 (6-OMe), 56.4 (7-OMe). The identity of luteolin (4), apigenin (5) and caffeic acid (6) was confirmed on the basis of m.p., spectroscopic evidence, notably UV, EIMS, $1 \mathrm{H}$, and NMR, and direct comparison with the published data.

\section{Acerosin bioactivity}

Due to the close relationship between the cytotoxic and the antioxidant activities, radical scavenging activity of acerosin was estimated and compared to ascorbic acid (positive control) using DPPH assay. The percentage of radical scavenging activity of acerosin was estimated as $84.5 \%$ at $100 \mu \mathrm{g} / \mathrm{ml}$ compared to $100 \%$ for ascorbic acid and $\mathrm{AEE}$ at the used concentration. Cytotoxic activity against HePG2 was evaluated using SRB and MTT assays. SRB assay showed $\mathrm{IC}_{50}$ of $24.69 \pm 1.24 \mu \mathrm{g} / \mathrm{ml}$ while MTT assay showed $\mathrm{IC}_{50}$ of $35.6 \pm 2.1$.

\section{Docking study}

A conformational search using an implicit solvent model was accomplished for acerosin; this was followed by refinement of the geometry of local minima through a quantum-mechanical (QM) method. Subsequently, flexible docking of the compound was performed in the crystallographic structure of the kinase enzyme (FAK) recovered from the Protein Data Bank (PDB ID 3PXK). The poses obtained for acerosin were found to bind in a co-crystallized ligand-like fashion with FAK, namely with Cys502, along with extra binding interactions with Glu430, Lys454 and Asp564 (Figures 1 and 2).

\section{Seed protein profiling}

The seed protein profile of $A$. fragrantissima species was studied and the observed protein banding profile is enlisted in Table 3, according to the molecular weight of the revealed bands. Protein band patterns were coded ' 0 ' or ' 1 ', depending on their absence or presence. The molecular weights observed ranged between 215 and 44 $\mathrm{KDa}$. The total number of bands recorded was 4 (Figure 3).

\section{DISCUSSION}

Cancer has created a challenge to the medical science researchers. Presently, cancer remains the second leading cause of death in the world, following cardiovascular diseases. In addition, cancer presents a rationally complex set of difficulties because of multiple sites and causation, inefficiently understood biology and numerous intervention approaches (Vicker et al., 2009). 


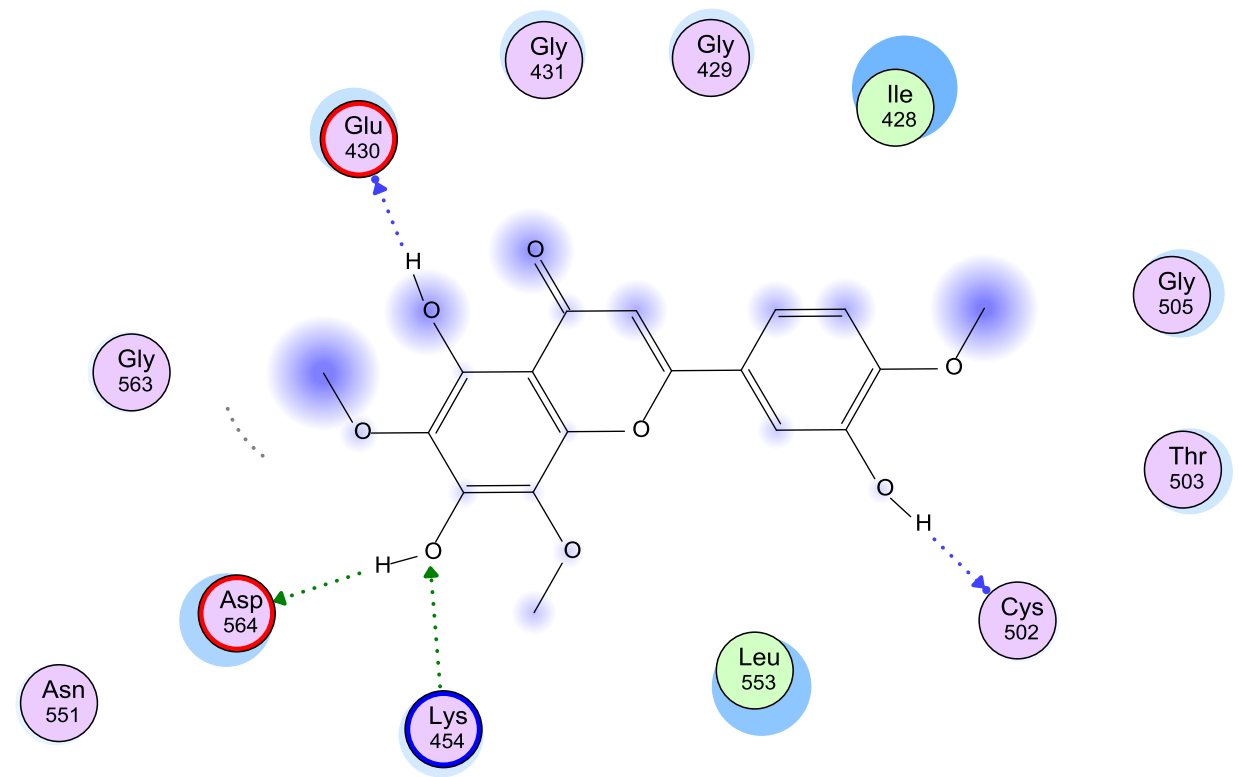

Figure 1. $2 \mathrm{D}$ docking of acerosin in the active pocket of FAK kinase. $\mathrm{S}=-12.33 \mathrm{Kcal} / \mathrm{mol}$.

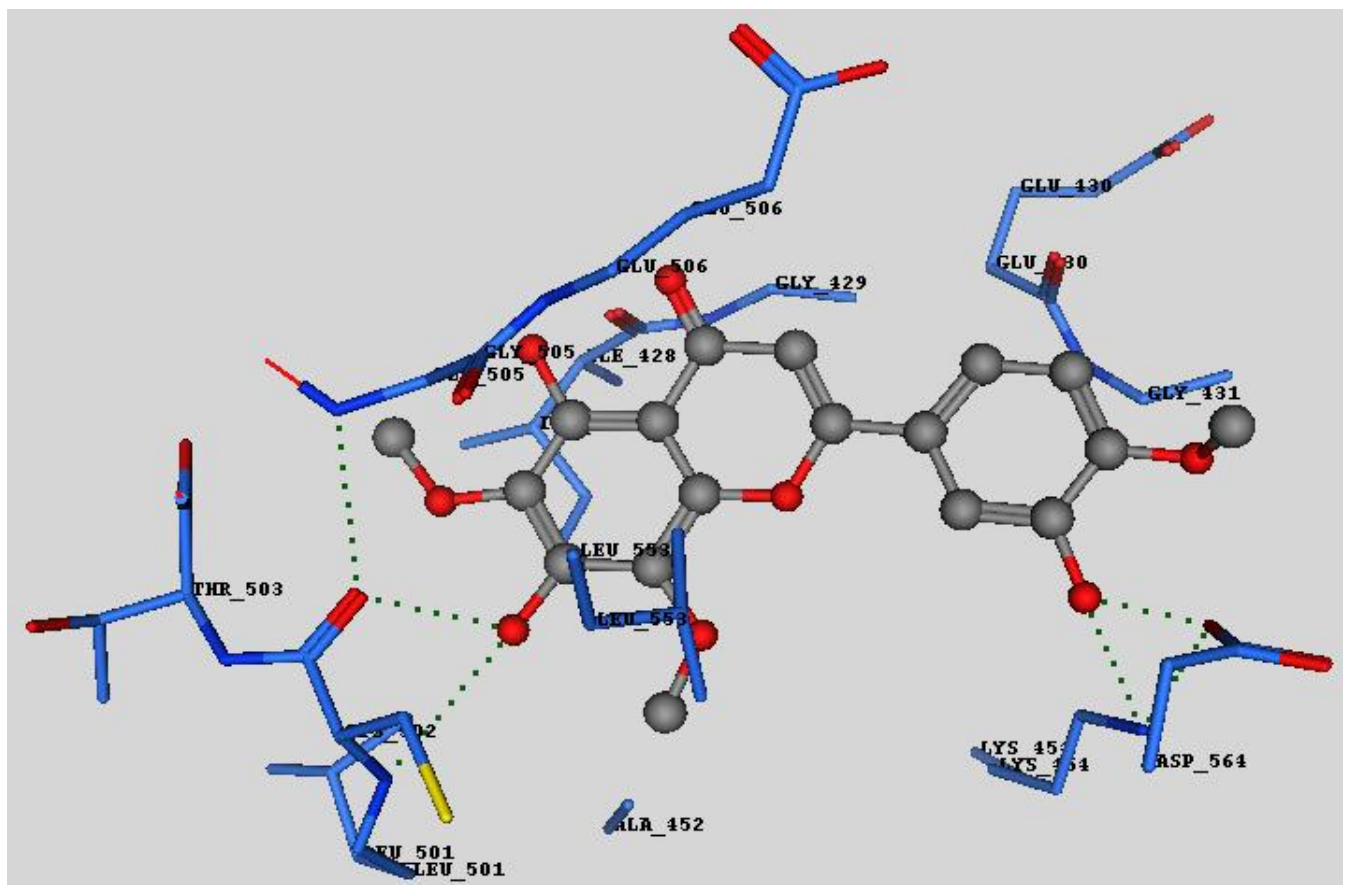

Figure 2. 3D docking of acerosin in the active pocket of FAK kinase.

Discovery of natural products with potential anticancer activity represents a key step in the development of anticancer therapy. Previous cytotoxic studies of different Achillea species revealed that flavonoids represent major cytotoxic agents. Santoflavone (tetramethyl flavone) isolated from $A$. talagonica Bioss. Is shown as a good cytotoxic agent using Brine shrimp method (Saeidnia et al., 2009). In addition, centaureidin (O-methylated flavonol) isolated from $A$. clavennae shows the highest cytotoxic activity, compared with other flavonoids and sesquiterpenes (Trifunovic et al., 2006). Enhancement of the lipophilicity of these molecules results in higher 


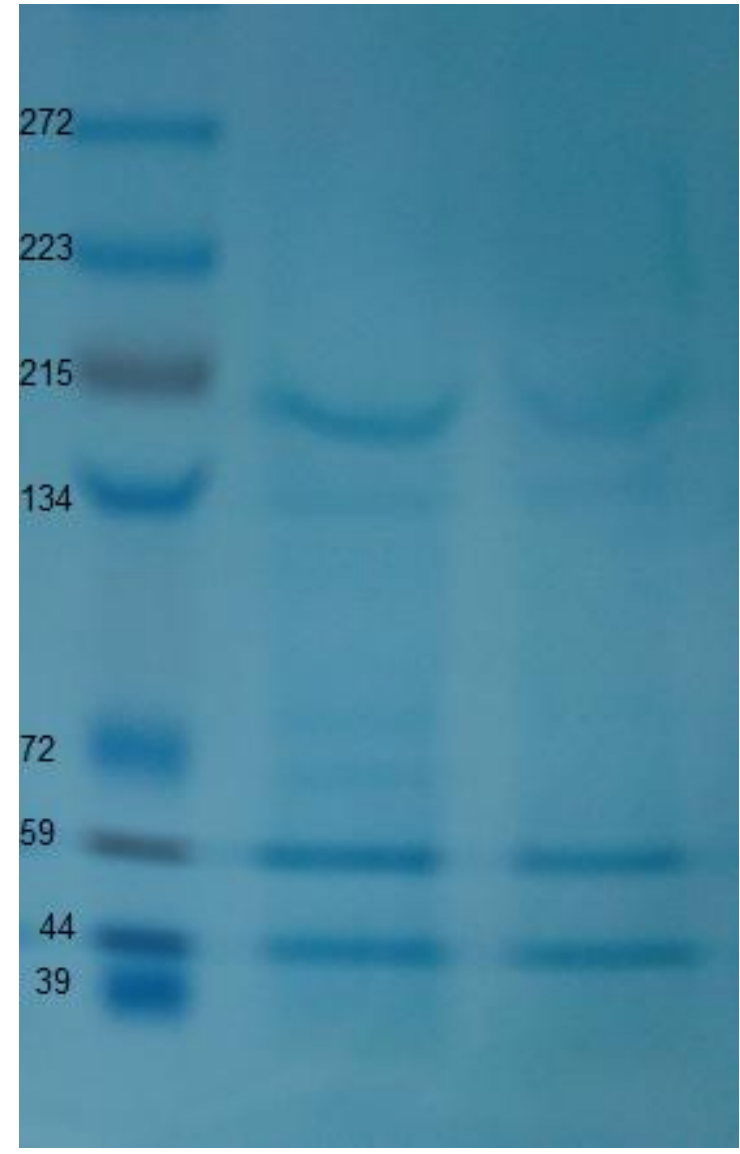

Figure 3. Protein profile of $A$. fragrantissima using SDS-PAGE.

potency (Ghantous et al., 2009).

Liver cancer is a very serious and solid tumor, which is highly endemic with hepatitis viruses. Egypt has the highest prevalence of hepatitis $\mathrm{C}$ virus (HCV) in the world, estimated nationally as $14.7 \%$ (El-zanaty and Way, 2008). In this study, $\mathrm{CH}_{2} \mathrm{Cl}_{2}$ fraction exhibited the highest effect against liver cell carcinoma with zero resistant fraction, therefore, prone to further isolation and purification procedures. Previous reports on $A$. alexandriregis Bornm. \& Rudsky revealed that combined chloroform and ethyl acetate extracts exhibit a pronounced cytotoxic effect against $\mathrm{HeLa}$ cancer cells $\left(\mathrm{IC}_{50}=\right.$ $25.92 \pm 4.96 \mu \mathrm{g} / \mathrm{ml}$ ) (Kundaković et al., 2005). Radical scavenging seems to play a considerable role in the antioxidant activity. In recent years, flavonoids have attracted a tremendous interest as potent-free radical scavengers and possible therapeutics against free radical mediated diseases (Middleton et al., 2000; Amić et al., 2003).

In order to identify the active components in the most effective fraction, $\mathrm{CH}_{2} \mathrm{Cl}_{2}$ extract was subjected to cellulose column and eluted fractions were grouped into four main fractions based on PC examination. Furthermore, purification using PPC and sephadex LH-20 resulted in the isolation of six compounds identified on the basis of spectral data (UV, NMR, El-MS) as well as comparison with published data (Wollenweber et al., 2003; Wallage, 1971; Mesquita et al., 1986; Lin et al., 2006; Bai et al., 2011; Nagao et al., 2002; Marder et al., 1996), and identified as five flavones (1-5) and one phenolic acid (6). Acerosin (1) was identified for the first time in genus Achillea.

Due to the higher yield of acerosin in the active fraction, further biological studies were conducted. Several assays have been developed for testing the cytotoxic activity. The effectiveness of SRB assay is frequently compared to that of MTT assay. SRB assay relies on the ability of SRB to bind to protein components of cells that have been fixed to plate by trichloroacetic acid, where the amount of dye extracted from stained cells is directly proportional to mass (Vichai and Kirtikara, 2006). The MTT assay requires cellular metabolic activity to convert the colorless tetrazolium to the purple colored formazan dye; therefore, it detects only viable cells. However, SRB assay is preferred to MTT assay, as SRB staining is independent of cell metabolic activity; therefore, fewer steps are required to optimize assay conditions for specific cell lines in SRB assay than in MTT assay (Keepers et al., 1991). IC I0 $_{50}$ tested with SRB assay was lower than MTT assay, in contrast to Rubinstein et al. (1990).

Due to the close relationship between the cytotoxic and the antioxidant activities, radical scavenging activity of acerosin was estimated and compared to ascorbic acid (positive control) using DPPH assay. The percentage of radical scavenging activity of acerosin was estimated as $84.5 \%$ at $100 \mu \mathrm{g} / \mathrm{ml}$ compared to $100 \%$ for ascorbic acid and $A E E$ at the used concentration.

Lower antioxidant effect of acerosin, compared with AEE, may be mainly due to the methylation at 4' position, as Rice-Evans et al. (1996) and Cao et al. (1997) studied the relationship between the antioxidant activities and structure of flavonoids and concluded that the hydroxyl groups in the C-3' and C-4' of the B-ring are essential for the antioxidant activities. On the other hand, synergistic effects between different isolated compounds suggested a higher radical scavenging activity for the crude extract. In an attempt to rationalize the cytotoxic activity profile exhibited by acerosin, a molecular modeling study was carried out. FAK, a member of the protein tyrosine kinases (PTK) family, was implicated in increased survival and invasiveness in human carcinoma. Acerosin was found to bind with FAK, namely with Cys502, along with extra binding interactions with Glu430, Lys454 and Asp564.

Luteolin's anticancer property was reported to be associated with the induction of apoptosis and inhibition of cell proliferation, metastasis and angiogenesis. Furthermore, 
luteolin sensitizes cancer cells to therapeutic-induced cytotoxicity by suppressing cell survival pathways (Lin et al., 2008). Luteolin and luteolin analogs act as potent FAK inhibitors, thus playing an important role in the reduction of cancer cell survival and migration (Huang et al., 2005). Seed protein profiling is one of the methods for characterizing different species. Further molecular studies are necessary for the identification of the genes encoding enzymes specific for flavone and flavone ether that are responsible for the activity in $A$. fragrantissima. Results of the present study have clearly demonstrated that aerial parts of $A$. fragrantissima possess pronounced cytotoxic activity. No reports related to the cytotoxic activity of $A$. fragrantissima extracts against hepatocellular carcinoma have been found so far. Besides this, this study is the first to identify acerosin in genus Achillea, showing its cytotoxic and radical scavenging activity.

\section{Conclusion}

Acerosin, isolated from dichloromethane extract in $A$. fragrantissima, displayed pronounced cytotoxic activity against liver cell carcinoma cell line, as well as high radical scavenging activity. This bioactive compound is a good candidate for possible semi-synthesis and derivatisation to enhance its activity as a lead compound in cancer therapy. Further researches would be needed for the exploration of its mechanism of action.

\section{ACKNOWLEDGEMENT}

The authors are thankful to Prof. Dr. Fatma A. Moharram for assisting in the interpretation of the structures of the isolated compounds.

\section{Conflict of interest}

The authors report no declarations of interest.

\section{REFERENCES}

Ahmed AA, Elsayed NH, Mabry TJ (1989). Flavonoids of Achillea santolina and $A$. fragrantissima. Rev. Latinoam. Quim. 20:5-7.

Ahmed AA, Jakupovk J, Seif El-din AA, Melek FR (1990).Irregular oxygenated monoterpenes from Achillea fragrantissima. Phytochemistry 29:1322-1324.

Ahmed AA, Shalaby AM, Melek FR, Mabry TJ (1988). Swertisin 2"arabinoside, a new c-glycosylflavone fromAchillea fragrantissima. J. Nat. Prod.51:971-972.

Al-Abd AM, Lee JH, Kim SY, Kun N, Kuh HJ (2008). Novel application of multicellular layers culture for in situevaluation of cytotoxicity and penetration of paclitaxel. Cancer Sci. 99:423-431.

Alenad AM, Al-Jaber NA, Krishnaswamy S, Yakout SM, Al-Daghri NM, Alokail MS (2013). Achillea fragrantissimaextract exerts its anticancer effect via induction of differentiation, cell cycle arrest and apoptosis in chronic myeloid leukemia (CML) cell line K562. J. Med. Plants Res. 7
(21):1561-1567

Amić D, Davidović D, Bešlo, D, Trinajstić N (2003). Structure- radical scavenging activity relationships of flavonoids.Croat.Chem. Acta 76(1):55-61.

Bai N, He K, Roller M, Lai C, Shao X, Pan M, Bily A, Ho C (2011). Flavonoid glycosides from Microteadebilis and their cytotoxic and anti-inflammatory effects. Fitoterapia 82:168-172.

Cao G, Sofic E, Prior RL (1997). Antioxidant and pro-oxidant behavior of flavonoids: Structure-activity relationships. Free Radic. Biol. Med. 22:749-760.

Chang CC, Yang MH, Wen HM, Chern JC (2002). Estimation of total flavonoid content in propolis by two complementary colorimetric methods. J. Food Drug Anal. 10:178-182.

Elmann A, Mordechay S, Erlank H, Telerman A, Rindner M, Ofir R (2011a). Anti-neuroinflammatory effects of the extract of Achillea fragrantissima. BMC Compl. Altern. Med. 11:98-124.

Elmann A, Telerman A, Mordechay S, Erlank H, Rindner M, Ofir R, BeitYannai E (2011b). Extract of Achillea fragrantissima downregulates ROS production and protects astrocytes from oxidative-stressinduced cell death. In: Chang, R.C., ed. Neurodegenerative Diseases-Processes, Prevention, Protection, and Monitoring, 435$452 \quad$ [online]. Available at: http://www.intechopen.com/books/neurodegenerative-diseasesprocesses-prevention-protection-and-monitoring/extract-of-achilleafragrantissima-downregulates-ros-production-and-protectsastrocytes-from-oxidati. Last accessed on January $8^{\text {th }}, 2012$.

EISayed EE (2010). Chemistry and biology of Achillea fragrantissima present in Sinai. Master dissertation, Suez Canal University, Egypt.

El-Zanaty F, Way A (2009). Egypt demographic and health survey 2008, Egyptian Ministry of Health, Cairo: El-Zanaty and associates and macro international.

Ezzat SM, Salama MM (2014). A new a-glucosidase inhibitor fromAchillea fragrantissima (Forssk.) Sch. Bip. growing in Egypt. Nat. Prod. Res. 28:812-818.

Ghantous A, Nasser N, Saab I, Darwiche N, Saliba NA (2009). Structure-activity relationship of seco-tanapartholides isolated fromAchillea falcatafor inhibition of HaCaT cell growth. Eur. J. Med. Chem. 44:3794-3797.

Huang YT, Lee LT, Lee PP, Lin YS, Lee MT (2005). Targeting of focal adhesion kinase by flavonoids and small-interfering RNAs reduces tumor cell migration ability. Anticancer Res. 25: 2017-2025.

Karihaloo JL, Kaur M, Singh S (2002). Seed protein diversity inSolanummelongena $\mathrm{L}$. and its wild and weedy relatives. Genet. Res. Crop Eval. 49:533-539.

Keepers YP, Pizao PE, Peters GJ, Van Ar-Otte J, Winograd B, Pinedo HM (1991). Comparison of sulforhodamine B protein and tetrazolium (MTT) assays for in vitro chemosensitivity testing. Eur. J. Cancer 27:897-900.

Khaled AT, Fawzi I, Adnan SJ, Magda E, Khaled MK (2010). Evaluation of antibacterial and antioxidant activities of methanolic extracts of some medicinal plants in Northern Part of Jordan. J. Biol. Sci. 10(4):325-332.

Kosalec H, Bakmaz M, Pepeljnjak S, Vladimir-kne S (2004). Quantitative analysis of the flavonoids in raw propolis from Northern Croatia. Acta Pharm. 54:65-72.

Kundaković T, Stanojković T, Juranić Z, Kovacević N (2005). Cytotoxic and antioxidant activity of Achillea alexandri-regis. Pharmazie 60:319-320.

Laemmli UK (1970). Cleavage of structural protein during the assembly of the head of Bacteriophage T4. Nature 227:680-685.

Lin C, Huang Y, Cheng L, Sheu S, Chen C (2006). Bioactive flavonoids from Ruellia tuberose. J. Chin. Med. 17:103-109.

Lin Y, Shi R, Wang X, Shen H M (2008). Luteolin, a flavonoid with potentials for cancer prevention and therapy. Curr. Cancer Drug Targets 8:634-646.

Lioi L, Sparvoli F, Bollini R (1999). Variation and genomic polymorphism of lectin related proteins inLima bean (Phaseoluslunatus L.) seeds. Genet. Resour. Crop Evol. 46:175-182.

Marder M, Viola H, Wasowski C, Wolfman C, Waterman PG, Medina $\mathrm{JH}$, Paladini AC (1996). Cirsiliol and caffeic acid ethyl ester, isolated from Salvia guaranitica, are competitive ligands for the central 
benzodiazepine receptors. Phytomedicine 3:29-31.

Mesquita AAL, Correa DDB, De Padua AP, Guedes MLO, Gottlieb O (1986). Flavonoids from four compositae species. Phytochemistry 25:1255-1256.

Middleton E Jr, Kandaswami C, Theoharides TC (2000). The effects of plant flavonoids on mammalian cells: implications for inflammation, heart disease and cancer. Pharmacol. Rev. 52:673-751.

Mosmann T (1983). Rapid colorimetric assays for cellular growth and survival: Application to proliferation and cytotoxicity assays. J. Immunol. Methods 65:55-63.

Mustafa EH, Abu Zarga M, Abdalla S (1992). Effects of cirsiliol, a flavone isolated fromAchillea fragrantissima, on rat isolated ileum. Gen. Pharmacol.23:555-560.

Nagao T, Abe F, Kinjo J, Okabe H (2002). Antiproliferative constituents in plants: 10 Flavones from the leaves of Lantana montevidensis BRIQ and consideration of structure-activity relationship. Biol. Pharm. Bull. 25:875-879.

Oktay M, Gulcin I, Kufrevioglu OI (2003). Determination of in vitro antioxidant activity of fennel (Foeniculumvulgare) seed extracts. LWT Food Sci. Technol.36:263-271.

Paradies I, Ohms JP (1987). Identification of triticale cultivars by electrophoresis of seed proteins. Landwirtschaftlich Forschung. 40:251-257.

Rice-Evans CA, Miller NJ, Paganga G (1996). Structure-antioxidant activity relationships of flavonoids and phenolic acids. Free Radic. Biol. Med. 20:933-956.

Rubinstein LV, Shoemaker RH, Paull KD, Simon RM, Tosini S, Skehan P, Scudiero DA, Monks A, Boyd MR (1990). Comparison of in vitro anticancer drug screening data generated with a tetrazolium assay versus a protein assay against a diverse panel of human tumor cell lines. J. Natl. Cancer Inst. 82:1113-1117.

Saeidnia S, Gohari AR, Mokhber-Dezfuli N, Kiuchi F (2011). A review on phytochemistry and medicinal properties of the genus Achillea. Daru. 19(3):173-186.

Saeidnia S, Moradi-Afrapoli F, Gohari AR, Malmir M (2009). Cytotoxic flavonoid fromAchillea talagonica Bioss. J. Med. Plants 8:52-56.

Saleh NAM (2003). Global phytochemistry: The Egyptian experience. Phytochemistry 63:239-241.

Sathiyamoorthy P, Lugasi-Evgi H, Van-Damme P, Abu-Rabia A, Gopas J, Golan-Goldhirsh A (1997). Larvicidal activity in desert plants of the Negev and Bedouin market plant products. Pharm. Biol. 35:265-273.
Segal RA, Duddeck DH, Kajtar M (1987). The sesquiterpene lactones from A. fragrantissima. Tetrahedron 43:4125-4132.

Sellappan S, Akoh CC (2002). Flavonoids and antioxidant capacity of Georgia-grown Vidalia onions. J. Agric. Food Chem. 50:5338-5342.

Shimada K, Fujikawa K, Yahara K, Nakamura T (1992). Antioxidative properties of xanthan on the autooxidation of soybean in cyclodextrin emulsion. J. Agric. Food Chem. 40:945-948.

Skehan P, Storeng R, Scudiero D, Monks A, McMahon J, Vistica D, Warren JT, Bokesch H, Kenney S, Boyd MR (1990). New colorimetric cytotoxicity assay for anticancer-drug screening. Natl. J. Cancer Inst. 82:1107-1112.

Soltan MM, Zaki AK (2009). Antiviral screening of forty-two Egyptian medicinal plants. J. Ethnopharmacol. 126:102-107.

Stegmann $H$, Burgermeister W, Shah AA, Francksen HE, Krogerrecklenfort E (1988). PANTA-PHOR and MONO-PHOR Manual. (Institut fur Biochemie, Biologische Bundesanstlt, Messeweg 11, D-3300 Braunschweig West Germany).

Thabrew MI, Hughes RD, McFarlane IG (1997). Screening of hepatoprotective plant components using a HepG2 cell cytotoxicity assay. J. Pharm. Pharmacol. 49:1132-1135.

Trifunovic S, Vajs V, Juranic Z, Zizak Z, Tesevic V, Macura S, Milosavljevic S (2006). Cytotoxic constituents of Achillea clavennaefrom Montenegro. Phytochemistry 68:887-893.

Vichai V, Kirtikara K (2006). Sulforhodamine B colorimetric assay for cytotoxicity screening. Nature protocols 1:1112-1116.

Vicker N, Sharland CM, Heaton WB, Gonzalez AM, Bailey HV, Smith A, Springall JS, Day JM, Tutill HJ, Reed MJ, Purohit A, Potter BV (2009). The design of novel 17-hydroxysteroid dehydrogenase type 3 inhibitors. Mol. Cell Endocrinol. 301:259-265.

Wallage JW (1971). Cirsimaritin-4'-O-rutinoside, a new flavone glycoside from Cirsiumbrevistylum. Phytochemistry 10:452-454.

Wollenweber E, Dörra M, Riverab D, Roitmanc JN (2003). Externally accumulated flavonoids in three Mediterranean Ononis species. Z. Naturforsch. 58c:771-775.

Yaniv Z, Dafni A, Friedman J, Palevitch D (1987). Plants used for the treatment of diabetes in Israel. J. Ethnopharmacol. 19:145-151. 